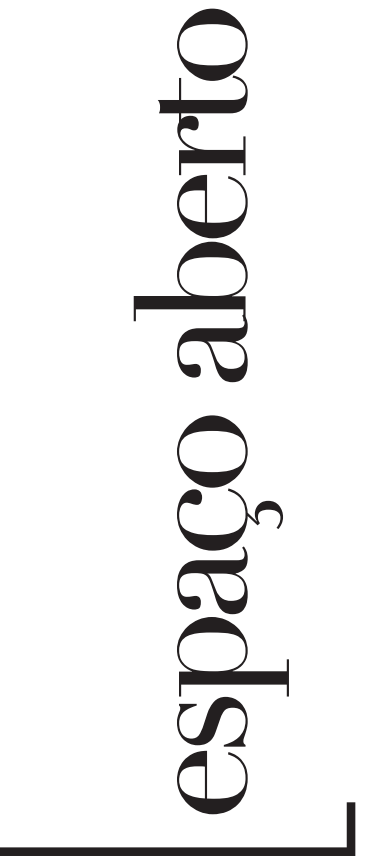

[ EDUARDO MOTTA ]

Artista plástico, estudou na Escola de Belas Artes da Universidade Federal

de Minas Gerais. Editor de moda do Sistema Usefashion de Informações e do blog

www.radarconsultoria.com. Consultor de moda da Radar Consultoria. Designer

e pesquisador com experiência na identificação e formulação de macrotendências.

Autor do livro 0 calçado e a moda no Brasil: um olhar histórico (Assintecal, 2005).

E-mail: eduardomotta@radarconsultoria.com
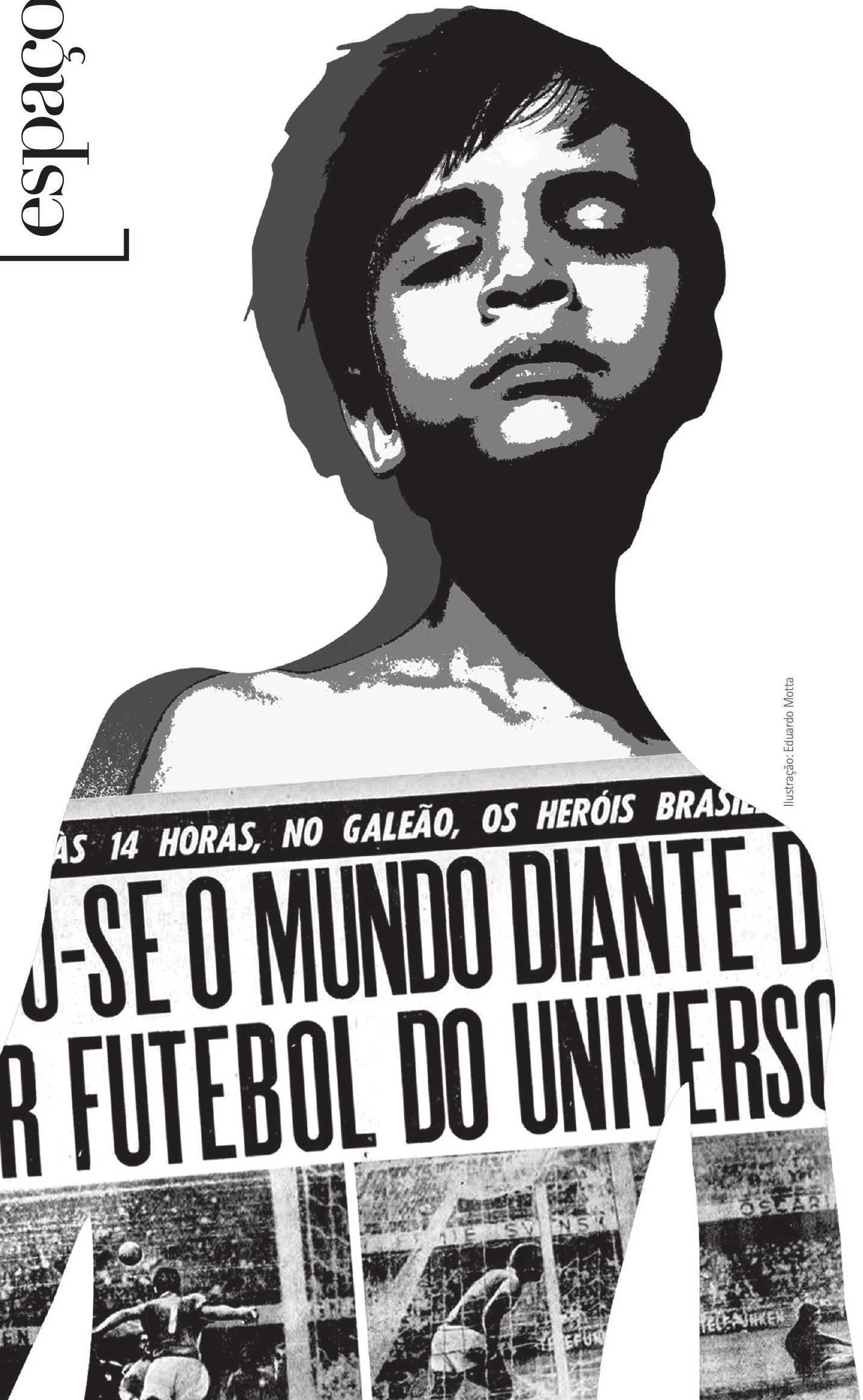


\section{Fora de jogo: uma experiência colateral}

Adulado nos superlativos da língua, o futebol é experiência do excesso - o maior estádio do mundo, o melhor time do mundo - e da tolerância equivalente. Paixão legítima no palavrão coletivo e, para alguns, até na violência da pancadaria generalizada. Mas o futebol é também a ginga natural e ondulante do zagueiro, a coreografia mortífera dos atacantes, a horda que se movimenta plástica e ruidosa como um corpo só nas arquibancadas, e é mesmo bonito de se ver.

No meu decisivo contato com ele, era a Copa de 70, e futebol, então, se traduzia em noventa milhões de braços, pernas e bandeiras em ação: a sincrônica máquina de festejar junto com os generais "Pra frente Brasil! Salve a seleção!".

Ainda que fosse um garoto e o futebol adrenalina e fúria, não me interessei por ele. É verdade que em nenhum momento desgostei. Apenas não gostei. E o que não é do gosto e da empatia não nos mobiliza. Essa não proximidade, e não necessariamente distanciamento, propiciaria vivências decisivas para as escolhas que fiz. Naquela copa do mundo mexicana, ao condicionar os ajuntamentos familiares em torno das tevês e criar silêncios de cemitério nas ruas da cidade interiorana, espessos como eu nunca vira, o futebol me presenteou com uma experiência do vazio na mesma intensidade de coisa absoluta que ele era.

Durante quase vinte dias e ao longo de nove jogos, tive a nítida sensação de que só eu permanecia, enquanto todo o resto não. No momento em que soava o apito e a partida começava, a mágica se instalava, sumindo com as gentes e os sons das casas. Nas ruas desertas se apreciava melhor aquele oco encravado no dia extraordinário, salpicado pela alternância de mudez e vozerio. Era estranhamente religiosa a expectativa que desaguava em rompantes de xingamentos, bebedeira e fervura de carnaval fora de época. Os quarteirões vazios, as fachadas mortas em estado de espera, de súbito cuspindo a multidão eufórica: isso não há como esquecer! Devo ao futebol a constatação assustadora e fundamental de que as coisas estão e não estão, de que têm parte e contraparte, e de que oscilam entre a morte e a celebração.

Essas polaridades assumiriam outras conotações. A ausência aguça diferenças, e quem não participa dos ritos coletivos não faz parte nem é igual. Mais tarde descobri outras formas de integração, outros usos para os estádios, abarrotados da mesma forma, só que eletrificados de rock'n'roll, e este não é, definitivamente, um depoimento da exclusão. Foi o reconhecimento da grandiosidade avassaladora do esporte que me propiciou, na razão inversa das suas dimensões, a chance de ocupar, desde cedo, um naco quieto da singularidade.

Dai por diante, e por muito tempo, o futebol esteve sempre lá. Como uma ausência. Inclusive da moda, subtraída no uniforme e na repetição. Não fui aos jogos, não torci por nenhum time, não vi pela televisão. Gostei dele nas mãos - atenção para 0 detalhe anatômico - do escritor Nelson Rodrigues, um apaixonado pelo assunto. Foi ele quem escreveu: "o pior cego é o que só vê a bola. A mais sórdida pelada é de uma complexidade shakespeariana"1.

Tempos depois, outras copas me divertiram razoavelmente, e devo assistir à próxima emocionado e barulhento como todo mundo. Contudo, volta e meia, o vazio em torno, sem gols, e insondável como silêncio de filme do Stanley Kubrick, vai se impor sobre a confusão. Disso, eu sei, e não posso nem quero evitar que seja assim. 